\title{
Productivity, cation absorption and severity of alternaria potato influenced by potassium fertilization
}

Produtividade, absorção de cátions e severidade de alternaria na batateira influenciadas pela adubação potássica

\author{
M. E. P. Soares ${ }^{1}$, A. C. P. Cavalcante ${ }^{1 *}$, G. A. V. de Andrade ${ }^{2}$, I. R. Barbosa ${ }^{1}$, N. J. C. \\ Lima $^{1}$, L. A. de Aquino ${ }^{1}$

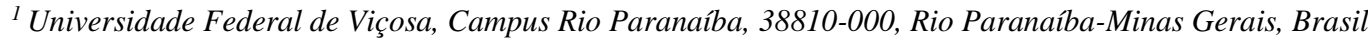 \\ ${ }^{2}$ Universidade Federal de Lavras, 37200-900, Lavras-Minas Gerais, Brasil
}

*cassio.alian216@gmail.com

(Recebido em 08 de dezembro de 2019, aceito em 13 de julho de 2020)

\begin{abstract}
Potassium $(\mathrm{K})$ is the nutrient most extracted by the potato crop and its deficiency drastically reduces productivity and increases early blight severity. Excessive $\mathrm{K}$ fertilization may reduce calcium $(\mathrm{Ca})$ and magnesium $(\mathrm{Mg})$ absorption and compromise productivity just as much as $\mathrm{K}$ deficiency. The influence of $\mathrm{K}$ fertilization on $\mathrm{Ca}, \mathrm{Mg}$ and $\mathrm{K}$ absorption is not documented for Asterix potato grown in clay soil. The objective of this study was to evaluate the absorption and partitioning of $\mathrm{K}, \mathrm{Ca}$ and $\mathrm{Mg}$ in the potato plant, in the productivity, and in the severity of early blight as a function of $\mathrm{K}_{2} \mathrm{O}$ doses. The treatments consisted of five doses of $\mathrm{K}: 0,150,300,500$, and 700 $\mathrm{kg} \mathrm{ha}^{-1}$ of $\mathrm{K}_{2} \mathrm{O}$. Doses were applied in two steps: $150 \mathrm{~kg} \mathrm{ha}^{-1}$ of $\mathrm{K}_{2} \mathrm{O}$ in the planting groove together with the $\mathrm{N}$ and $\mathrm{P}$ and the remainder of each dose, with broadcast fertilization preceding the hilling process that took place 21 days after planting. Early blight severity and the number of small tubers decreased, while the number of large tubers increased as a function of $\mathrm{K}$ doses. The optimal dose for total productivity was $291.3 \mathrm{~kg} \mathrm{ha}^{-1}$ of $\mathrm{K}_{2} \mathrm{O}$. In addition, the absorption of $\mathrm{Ca}$ and $\mathrm{Mg}$ were reduced by high doses of $\mathrm{K}$, which shows that the doses of this nutrient must be consistent with the extraction of the potato crop.

Keywords: Alternaria solani, Solanum tuberosum, tuber quality.
\end{abstract}

O potássio (K) é o nutriente mais extraído pela cultura da batata e sua deficiência reduz drasticamente a produtividade e aumentar a severidade de alternaria. Adubações excessivas com $\mathrm{K}$ podem reduzir a absorção de cálcio $(\mathrm{Ca})$ e de magnésio $(\mathrm{Mg})$ e comprometer a produtividade tanto quanto a deficiência de $\mathrm{K}$. A influência da adubação com K sobre a absorção de $\mathrm{Ca}, \mathrm{Mg}$ e K não é documentada para a batata Asterix cultivada em solo argiloso. Portanto, objetivou-se avaliar a absorção e partição de $\mathrm{K}, \mathrm{Ca}$ e $\mathrm{Mg}$ na batateira, produtividade e a severidade de alternaria em função das doses de $\mathrm{K}_{2} \mathrm{O}$. Os tratamentos consistiram de cinco doses de $\mathrm{K}$ : 0, 150, 300,500 e $700 \mathrm{~kg} \mathrm{ha}^{-1}$ de $\mathrm{K}_{2} \mathrm{O}$. As doses foram aplicadas em duas etapas: $150 \mathrm{~kg} \mathrm{ha}^{-1}$ de $\mathrm{K}_{2} \mathrm{O}$ no sulco de plantio juntamente com o $\mathrm{N}$ e $\mathrm{P}$ e o restante de cada dose, a lanço antecedendo a operação de amontoa que foi realizada aos 21 dias após o plantio. A severidade de alternaria e o número de tubérculos miúdos diminuíram, enquanto que o de tubérculos graúdos aumentou em função das doses de K. A dose ótima para a produtividade total foi de 291,3 $\mathrm{kg} \mathrm{ha}^{-1}$ de $\mathrm{K}_{2} \mathrm{O}$. Além disso, a absorção de $\mathrm{Ca}$ e $\mathrm{Mg}$ foram dificultadas por altas doses de $\mathrm{K}$, o que demonstra que as doses desse nutriente devem ser condizentes com a extração da cultura da batata.

Palavras chave: Alternaria solani, Solanum tuberosum, qualidade de tubérculo.

\section{INTRODUCTION}

The potato (Solanum tuberosum L.) is one of the most consumed foods in the world due to its high nutritional value, as it is rich in vitamins, proteins and nutrients essential to nourishment [1]. In potato cultivation, high productivity are achieved with rational management of irrigation, potato seed quality and fertilization among other factors [2]. Several studies have demonstrated the positive relationship between fertilization and potato crop productivity, as well as the quality of the tubers produced $[3,4,5]$.

The Mondial and Asterix varieties are the most productive and present higher macronutrient extraction, especially Asterix, which presents higher $\mathrm{N}, \mathrm{P}, \mathrm{K}$ and $\mathrm{Mg}$ exports, potassium (K) is the most extracted nutrient by the potato plant and it influences the productivity and quality of tubers $[6,7]$. This is because it provides increased tubercle productivity, as well as increasing the rate of commercial 
tubers, the average weight of the tubers and the starch content, plus reducing the content of reducing sugar [8].

The application of $\mathrm{K}$ without partitioning can result in losses due to leaching mainly in sandy soils and conditions of high rainfall, thus reducing the availability for the plant at the end of the cycle $[9,10]$. In addition to influencing productivity, $\mathrm{K}$ deficiency can reduce the number of leaves and result in thinner and shorter stems. Under acute deficiency, there is reduced growth and early potato leaf senescence $[11,12]$.

Increasing the concentration of $\mathrm{K}$ in the solution may lead to lower absorption of $\mathrm{Ca}$ and $\mathrm{Mg}$. This is because $\mathrm{K}$ can interfere with the electrochemical balance of cells, affecting the absorption and physiological availability of $\mathrm{Ca}^{2+}$ and $\mathrm{Mg}^{2+}[13,14]$. In addition to the quantitative aspect, potassium fertilizers should consider equilibrium with cations such as $\mathrm{Ca}$ and $\mathrm{Mg}$, since monovalent cations are absorbed faster than bivalent ones by the roots, so an adequate relation between them is fundamental to increase absorption efficiency $[15,16]$.

The early blight is an important disease in the potato crop caused by the Alternaria solani fungus. It presents a higher incidence in the summer due to high temperature and humidity and is also related to nutrient deficiency [17]. K nutrition interferes in several physiological and biochemical processes relevant to the susceptibility of plants to pathogens and insects [18]. The $\mathrm{P}$ and $\mathrm{K}$ nutrients make the plants more resistant to $A$. solani. On the other hand, $\mathrm{N}$ makes the tissue more suculent and more sensitive to infection by the fungus. Plant resistance caused by high doses of $\mathrm{K}$ is independent of the pathogen type [19].

Adequate $\mathrm{K}$ nutrition may favor increased $\mathrm{Ca}$ and $\mathrm{Mg}$ absorption and resistance to A. solani and thereby increase potato crop productivity. Therefore, the objective of this study was to evaluate the productivity, cation absorption and early blight severity influenced by potassium fertilization in potatoes of the Asterix variety.

\section{MATERIAL AND METHODS}

The experiment was carried out in the city of Rio Paranaíba-MG, at the experimental station of the Instituto Pesquisa Agrícola do Cerrado - IPACER, from June to October 2016. The soil of the experimental area is classified as Yellow Red Latosol with a very clayey texture. For the layer from 0 to $30 \mathrm{~cm}$ depth, its chemical analysis showed: $\mathrm{pH}$ in $\mathrm{H}_{2} \mathrm{O}=5.9 ; \mathrm{P}=2.5 ; \mathrm{K}^{+}=38.0 ; \mathrm{S}=26.0 ; \mathrm{B}=0.27$; $\mathrm{Cu}=5.6 ; \mathrm{Fe}=40 ; \mathrm{Mn}=19.8$ and $\mathrm{Zn}=2.1 \mathrm{mg} / \mathrm{dm}^{3} ; \mathrm{Ca}^{2+}=5.0 ; \mathrm{Mg}^{2+}=1.0 ; \mathrm{CTC}=10.4 \mathrm{cmol}_{\mathrm{d}} / \mathrm{dm}^{3} ; \mathrm{M} . \mathrm{O}$ $\left(\mathrm{g} / \mathrm{dm}^{3}\right)=3.6$; P-remaining $(\mathrm{mg} / \mathrm{L})=15.3$.

The planting was done manually, on 06/07/16, with three potato seeds type I per row meter of the Asterix variety. The soil was prepared with a plow, a rack and a rotary hoe operation. In the plantation fertilization, $920 \mathrm{~kg} \mathrm{ha}^{-1} \mathrm{P}_{2} \mathrm{O}_{5}, 130 \mathrm{~kg} \mathrm{ha}^{-1}$ of $\mathrm{N}$, and $150 \mathrm{~kg} \mathrm{ha}^{-1}$ The nitrogen (N) source used was urea $(45 \% \mathrm{~N})$, of $\mathrm{K}_{2} \mathrm{O}$ were used in the planting groove (except in the control treatment - without $\mathrm{K}$ ). Phytosanitary and irrigation management were carried out according to the crop's monitoring and needs.

The treatments consisted of five doses of $\mathrm{K}: 0,150,300,500$, and $700 \mathrm{~kg} \mathrm{ha}^{-1} \mathrm{of} \mathrm{K}_{2} \mathrm{O}$. Doses were applied in two steps: $150 \mathrm{~kg} \mathrm{ha}^{-1}$ of $\mathrm{K}_{2} \mathrm{O}$ in the planting groove together with the $\mathrm{N}$ and $\mathrm{P}$ and the remainder of each dose, with broadcast fertilization preceding the hilling process that took place 21 days after planting (DAP). The experimental design was made up of randomized blocks with four replicates. The plots were composed of four six-meter-long rows of plants, spaced $0.87 \mathrm{~m}$ apart. The two central rows were considered useful. Between plots, a space of 1 meter was left to avoid contamination.

At 66 and 80 DAP (full tubing and initial maturation, respectively), the severity of the early blight was evaluated. To assess severity, the diagrammatic scale for the disease was used Reifschneider (1987) [20], as adapted by Azevedo (1997) [21]. Harvest occurred at 96 DAP. The tubers were classified by equatorial diameter as large $(>42 \mathrm{~mm})$ and small $(<42 \mathrm{~mm})$. The total productivity productivity was obtained by adding the two sizing classes. Tuber and shoot samples were submitted to oven drying with forced air ventilation at $75^{\circ} \mathrm{C}$ for 72 hours. The samples were ground in a Willey type mill and passed through a $1.27 \mathrm{~mm}$ sieve to determine the $\mathrm{Ca}, \mathrm{Mg}$ and $\mathrm{K}$ contents according to the methods described in Malavolta et al. (1997) [22]. The accumulations of $\mathrm{K}, \mathrm{Ca}$ and $\mathrm{Mg}$ were calculated by the product between the contents of these nutrients and the dry matter of shoot and tubers. The extraction of nutrients was the sum of the contents in the aerial part and the tubers.

For statistical analysis, the data were initially submitted to verification of normality and homogeneity of the variances. Subsequently, the data were submitted to analysis of variance (ANOVA) and regression 
analysis was performed at 5\% level. The SPEED Stat spreadsheet software Carvalho \& Mendes, 2017 [23], was used for statistical analysis.

\section{RESULTS AND DISCUSSION}

Aerial dry matter (ADM) productivity was influenced by potassium fertilization, with an estimated accumulation of $1506 \mathrm{~kg} \mathrm{ha}^{-1}$ at a dose of $115.1 \mathrm{~kg} \mathrm{ha}^{-1}$ of $\mathrm{K}_{2} \mathrm{O}$ corresponding to $95 \%$ of maximum ADM (Figure 1). ADM is usually the net measure of potato response to fertilization [24]. The peak development of the aerial part coincides with the rate of maximum assimilation of $\mathrm{K}$ by the plants [17, 25]. Therefore, $\mathrm{K}$ deficiency causes a reduction in the accumulation of ADM, of the leaf area and, consequently, of early senescence $[12,26]$.

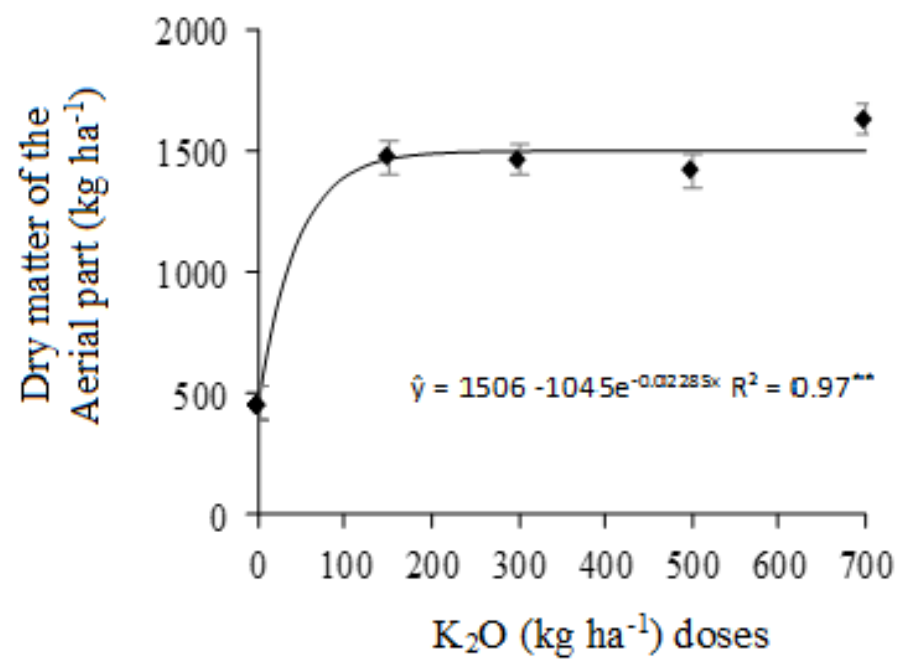

Figure 1: Aerial dry matter (ADM) of the potato as a function of the doses of $\mathrm{K}_{2} \mathrm{O}$.

The severity of early blight in potato plants at 66 and 80 DAP decreases exponentially as a function of the $\mathrm{K}$ doses (Figure 2). At 66 DAP, a dose of $317.7 \mathrm{~kg} \mathrm{ha}^{-1} \mathrm{~K}_{2} \mathrm{O}$ was required to reach $95 \%$ of the minimum severity. At $80 \mathrm{DAP}$, the fertilization requirement to minimize early blight severity was higher and required $521.1 \mathrm{~kg} \mathrm{ha}^{-1}$ of $\mathrm{K}_{2} \mathrm{O}$ to obtain $95 \%$ of the minimum severity. This response is related to the redistribution of $\mathrm{K}$ and $\mathrm{N}$ in the plant. In the vegetative phase, the amount of nutrients in the leaves is higher than in the tuberization phase, so the plant becomes more susceptible starting from the tuberization phase [27].
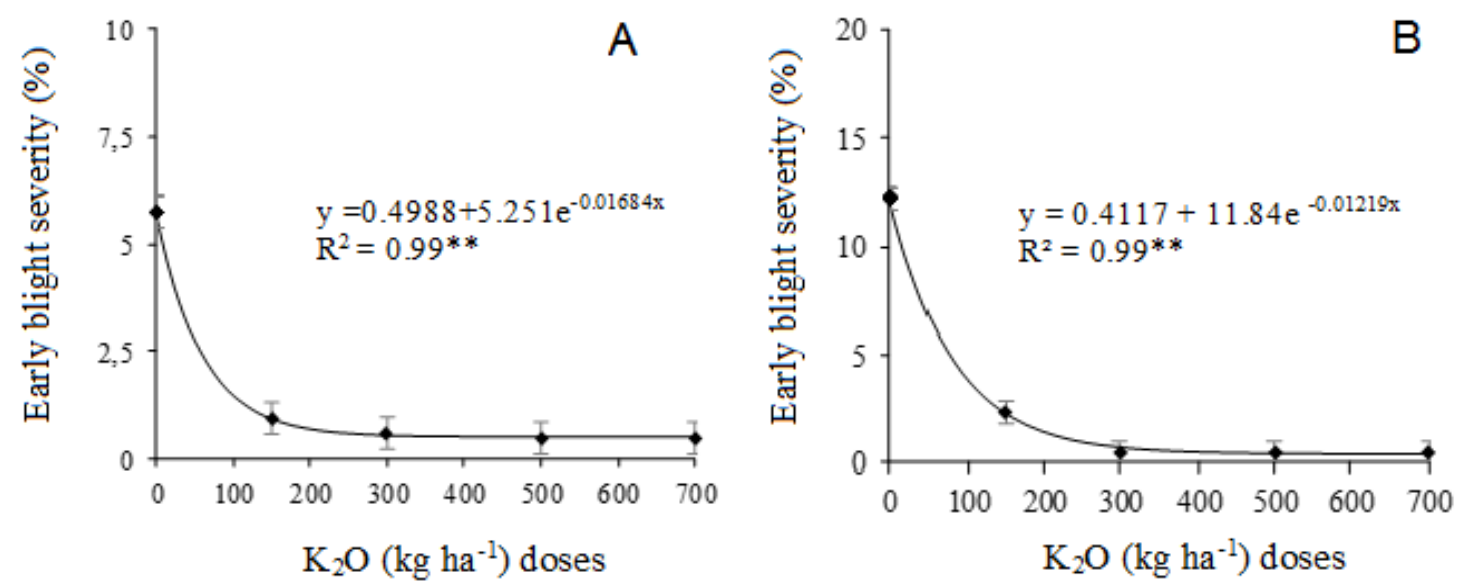

Figure 2: Early blight severity at $66 \mathrm{DAP}(\mathrm{A})$ and $80 \mathrm{DAP}(\mathrm{B})$ as a function of the doses of $\mathrm{K}_{2} \mathrm{O}$ in the potato.

The retranslocation of $\mathrm{K}$ in large quantities to the tubers and of $\mathrm{N}$ to a lesser extent increases the susceptibility of potato to pathogens throughout the phenological cycle [28]. Higher fertilizations with 
$\mathrm{K}$ may decrease or delay the depletion of $\mathrm{K}$ in the leaves and thereby reduce the severity of early blight [17]. K deficiency increases the concentration of low molecular weight and $\mathrm{N}$ compounds in the sap, favoring increased disease severity [17, 29]. Possibly because there are more amino acids in the sap, there is greater succulence to the plant and it is easier for the pathogens to enter the tissues and cause diseases [30, 31].

The productivity of tubers smaller than $42 \mathrm{~mm}$ (small) decreased and those larger than $42 \mathrm{~mm}$ (big) increased in a quadratic manner with increasing potassium doses (Figures 3A and 3B). The highest productivity of small tubers was without application of $\mathrm{K}$, and the lowest was with the dose of $591.3 \mathrm{~kg}$ $\mathrm{ha}^{-1} \mathrm{~K}_{2} \mathrm{O}$. The reduction of small tubers reflected a higher productivity of big tubers, whose estimated productivity of $46.69 \mathrm{t} \mathrm{ha}^{-1}$ (corresponding to $95 \%$ of the maximum) was reached with the dose of 330 $\mathrm{kg} \mathrm{ha}^{-1} \mathrm{~K}_{2} \mathrm{O}$ (Figures $3 \mathrm{~A}$ and $3 \mathrm{~B}$ ). Other studies report the positive effect of potassium fertilization on the percentage of tubers marketable by the increase of medium and large tubers, which are more acceptable to the consumer $[8,26]$. This is due to the influence of $\mathrm{K}$ on photosynthesis in the conversion of assimilates and also as an enzymatic activator of starch synthesis, which can increase the starch content and consequently increase the quality of the tuber [32,33]. $\mathrm{K}$ is important in the redistribution of sugars and in the synthesis of starch $[12,13]$.
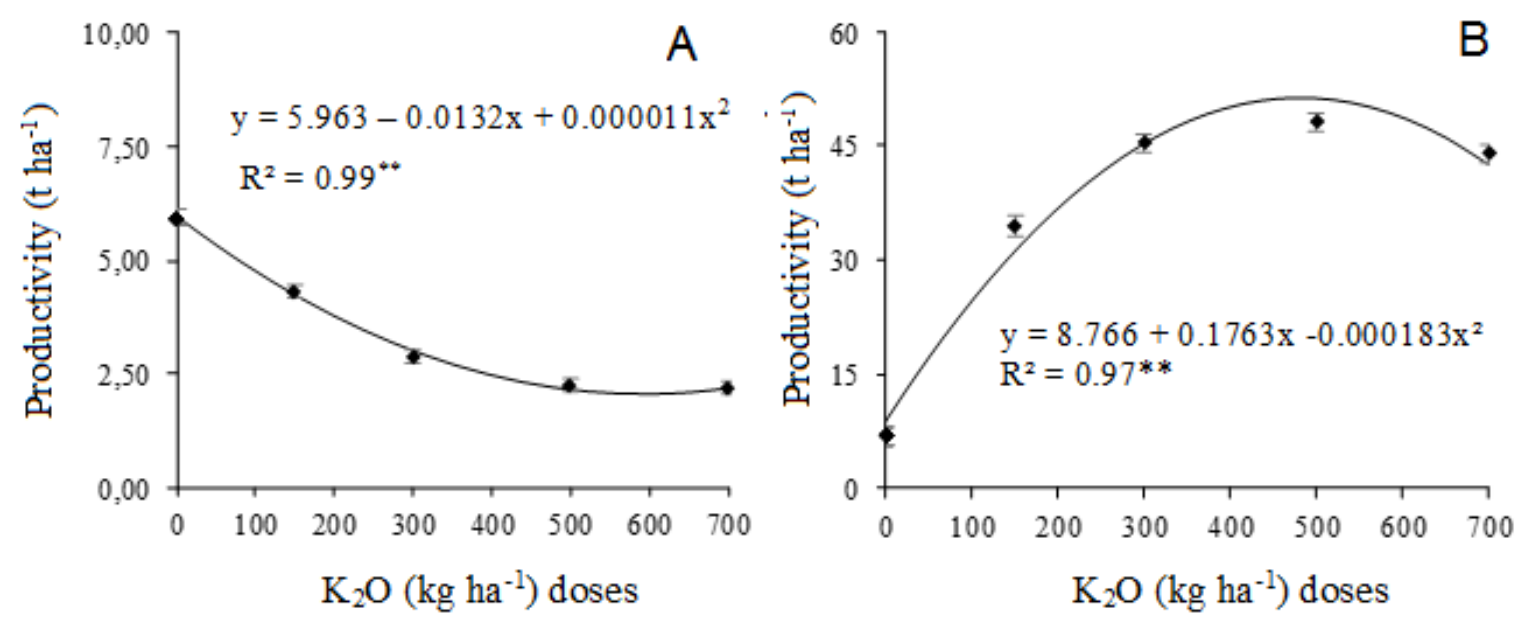

Figure 3: Productivity of tubers smaller (A) and larger (B) than $42 \mathrm{~mm}$ as a function of $\mathrm{K}_{2} \mathrm{O}$ doses.

The total productivity of the tubers was increased by potassium fertilization (Figure 4). The maximum productivity at $95 \%$ efficiency was obtained with the $291.3 \mathrm{~kg} \mathrm{ha}^{-1} \mathrm{~K}_{2} \mathrm{O}$ dose, respectively. $\mathrm{K}$ doses greater than the one corresponding to $95 \%$ of the maximum productivity increase the cost of production and favor the accumulation of $\mathrm{K}$ by the potato, but without a positive reflection on the net revenue obtained with the productivity increase [34, 35]. Further research by Zhang et al. (2018) [7], also obtained maximum productivity of tubers at the dose of $270 \mathrm{~kg} \mathrm{ha}^{-1}$ with a productivity of $37 \mathrm{t} \mathrm{ha}^{-1}$, values close to the present research that obtained productivity above $45 \mathrm{t} \mathrm{ha}^{-1}$. The excess $\mathrm{K}$ can cause imbalances such as excess leaf production, elongation of the growth and maturation period, reduction of the tuberization period and less starch in the tubers and less productivity [5, 7]. 


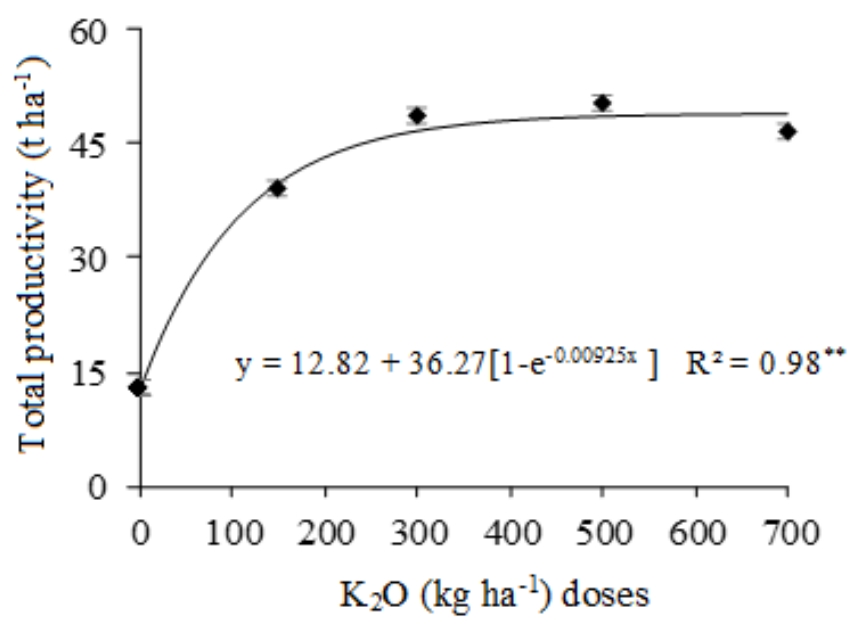

Figure 4: Total productivity of potato tubers due to $\mathrm{K}_{2} \mathrm{O}$ doses.

The fertilization with $\mathrm{K}$ influenced the nutrient content linearly in the aerial part, which reached 70 $\mathrm{kg} \mathrm{ha}^{-1}$ of $\mathrm{K}$ with the fertilization of $700 \mathrm{~kg} \mathrm{ha}^{-1}$ of $\mathrm{K}_{2} \mathrm{O}$ (Figure $5 \mathrm{~B}$ ). The highest content of $\mathrm{Ca}$ in the aerial part (Figure $5 \mathrm{C}$ ) was $44 \mathrm{~kg} \mathrm{ha}^{-1}$ at the dose of $278 \mathrm{~kg} \mathrm{ha}^{-1} \mathrm{~K}_{2} \mathrm{O}$, which was the maximum value of potassium fertilizer that does not interfere with the absorption of $\mathrm{Ca}$ by the potato plant (Figure $5 \mathrm{D}$ ). Although the $\mathrm{K}$ doses influenced $\mathrm{Mg}$ accumulation in the aerial part, it was not possible to adjust the significant mathematical model (Figure 5F). This decrease in $\mathrm{Ca}$ and $\mathrm{Mg}$ contents occurs through the antagonistic competitive absorption of $\mathrm{K}$ and $\mathrm{Mg}$ [36]. The partitioned fertilization with $100 \mathrm{~kg} \mathrm{ha}^{-1}$ of $\mathrm{K}$ increased $\mathrm{Mg}$ foliar content in relation to the single application in planting, which was attributed to the lower competition between $\mathrm{K}$ and $\mathrm{Mg}$ at root absorption sites [14]. 

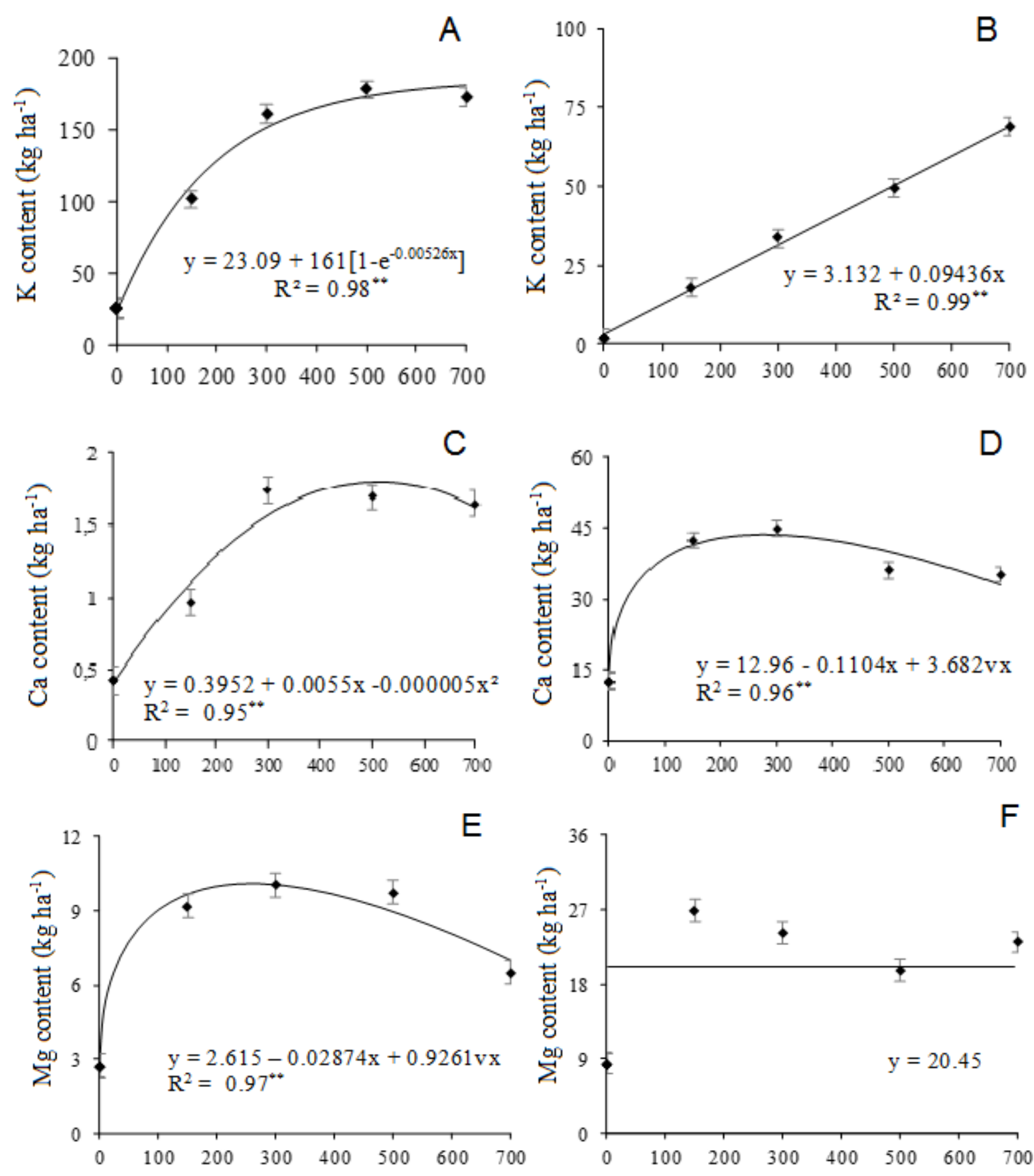

$\mathrm{K}_{2} \mathrm{O}\left(\mathrm{kg} \mathrm{ha}^{-1}\right)$ doses

$\mathrm{K}_{2} \mathrm{O}\left(\mathrm{kg} \mathrm{ha}^{-1}\right)$ doses

Figure 5: $\mathrm{K}, \mathrm{Ca}$ and $\mathrm{Mg}$ nutrient content in tubers (A, $\mathrm{C}$ and $\mathrm{E})$ and aerial part (B, $\mathrm{D}$ and $\mathrm{F})$ due to $\mathrm{K}_{2} \mathrm{O}$ doses.

The content of $\mathrm{K}$ in the tubers (Figure 5A) increased according to the mathematical model of Mitscherlich and $95 \%$ of the maximum accumulation was reached with the dose of $545 \mathrm{~kg} \mathrm{ha}^{-1} \mathrm{~K}_{2} \mathrm{O}$. At the optimum economic dose $\left(291.3 \mathrm{~kg} \mathrm{ha}^{-1}\right.$ of $\left.\mathrm{K}_{2} \mathrm{O}\right)$ the estimated $\mathrm{K}$ accumulation in the tubers was $149.3 \mathrm{~kg} \mathrm{ha}^{-1}$ of $\mathrm{K}$. The maximum estimated Ca content in the tubers was $1.8 \mathrm{~kg} \mathrm{ha}^{-1}$ at the dose of 383 $\mathrm{kg} \mathrm{ha}^{-1} \mathrm{~K}_{2} \mathrm{O}$ (Figure $5 \mathrm{C}$ ).

The increase in $\mathrm{K}$ doses resulted in a decrease in $\mathrm{Mg}$ content in the tubers, which was at a maximum $10 \mathrm{~kg} \mathrm{ha}^{-1}$ with the $260 \mathrm{~kg} \mathrm{ha}^{-1}$ dose of $\mathrm{K}_{2} \mathrm{O}$ (Figure $5 \mathrm{E}$ ). Consequently, increased $\mathrm{K}$ application reduced the uptake of $\mathrm{Ca}$ and $\mathrm{Mg}$. This can be explained by the fact that high doses of $\mathrm{K}$ can interfere with the electrochemical balance of cells and affect the absorption and physiological availability of $\mathrm{Ca}$ and $\mathrm{Mg}$ $[13,14]$. Excessive doses of $\mathrm{K}$ may result in salination and imbalance in $\mathrm{Ca}^{+}$and $\mathrm{Mg}^{2+}$ cations [37]. In addition to the quantitative aspect, potassium fertilizers should consider equilibrium with cations such 
as $\mathrm{Ca}$ and $\mathrm{Mg}$, since monovalent cations are absorbed faster than bivalent ones by the roots, so an adequate relation between them is fundamental to increase absorption efficiency [15, 16]. Therefore, excessive applications of potassic fertilizers should be avoided in order to avoid luxury absorption and avoid interference in the absorption of $\mathrm{Mg}$ and $\mathrm{Ca}$ by the plants [35].

\section{CONCLUSIONS}

Potassium fertilization promoted increased productivity and the optimal dose for the Asterix variety in low availability clay soil was $291 \mathrm{~kg} \mathrm{ha}^{-1}$ of $\mathrm{K}_{2} \mathrm{O}$.

Excessive doses of potassium reduced the absorption of $\mathrm{Ca}$ and $\mathrm{Mg}$ by the potato plant. The severity of potato early blight decreases with increasing doses of potassium.

\section{REFERENCES}

1. Narváez-Cuenca CE, Peña C, Restrepo-Sánchez LP, Kushalappa A, Mosquera T. Macronutrient contents of potato genotype collections in the Solanum tuberosum Group Phureja. J Food Compost Anal. 2018 Mar;66:179-184, doi: 10.1016/j.jfca.2017.12.019

2. Ierna A, Mauromicale G. Potato growth, yield and water productivity response to different irrigation and fertilization regimes. Agric Water Manag. 2018 Mar;201:21-26, doi: 10.1016/j.agwat.2018.01.008.

3. Mallmann N, Lucchesi LAC, Deschamps C. Influência da adubação com NPK na produção comercial e rentabilidade da batata na região Centro-Oeste do Paraná. Rev Bras Tecn Aplic Ciênc Agrar. 2011 Set;4(3):6782.

4. Luz JMQ, Queiroz AA, Oliveira RC. Teor crítico foliar de nitrogênio na batata 'Asterix' em função de doses de nitrogênio. Hortic Bras. 2014 Abr;32(2):225-229, doi: 10.1590/S0102-05362014000200019.

5. Kawakami J. Redução da adubação, doses e parcelamento de nitrogênio no crescimento e produtividade de batata. Hortic Bras. 2015 Abr;33(2):168-173, doi: 10.1590/S0102-053620150000200006.

6. Fernandes AM, Soratto RP, Silva BL. Extração e exportação de nutrientes em cultivares de batata: I macronutrientes. R Bras Ci Solo. 2011 Nov;35(6):2039-2056, doi: 10.1590/S0100-06832011000600020.

7. Zhang W, Liu X, Wang P, Zhang H, Li M, Song B, Zhao Z. Effects of potassium fertilization on potato starch physicochemical properties. Int J Biol Macromol. 2018 Out;117:0141-8130, doi: 10.1016/j.ijbiomac.2018.05.131.

8. Li S, Duan Y, Guo T, Zhang P, He P, Johnston A, Shcherbakov A. Potassium management in potato production in Northwest region of China. Field Crops Res. 2015 Mar;174:48-54, doi: 10.1016/j.fcr.2015.01.010.

9. Raij VB, Canterella H, Quaggio JA, Furtani AMC. Recomendações de adubação e calagem para o Estado de São Paulo. Campinas: Instituto Agronômico \& Fundação IAC. 1997. 285 p.

10. Echer FR. Nutrição e adubação da batata-doce. Presidente Prudente: Universidade do Oeste Paulista; 2015.94 p.

11. Mallmann N, Lucchesi LAC. Efeito da adubação na produtividade, qualidade e sanidade de batata cultivada no centro-oeste Paranaense. Sci Agrar. 2002;3(1):113-132, doi: 10.5380/rsa.v3i1

12. Silva HRF, Fontes PCR. Adubação potássica e seu efeito residual sobre a produtividade e a qualidade de tubérculos de batata. Pesq Agropec Bras. 2016 Jul;51(7):842-848, doi: 10.1590/S0100-204X2016000700007.

13. Reis Júnior RA, Fontes PCR, Neves JCL, Santos NT. Total soil electrical conductivity and critical soil $\mathrm{K}^{+}$to $\mathrm{Ca}^{2+}$ and $\mathrm{Mg}^{+2}$ ratio for potato crops. Sci Agric 1999 Out;56(4):985-989, doi: 10.1590/S010390161999000400030 .

14. Job ALG. Doses e parcelamento da adubação potássica na cultura da batata. [dissertação]. Botucatu: Faculdade de Ciências Agronômicas da UNESP, 2014. 70 p.

15. Marques DJ, Broetto F, Silva EC, Carvalho JG. Dinâmica de cátions na raiz e folhas de berinjela cultivada sobre doses crescentes de potássio oriundas de duas fontes. Idesia. 2011 Ago;29(2):69-77, doi: 10.4067/S071834292011000200009.

16. Montes RM, Parent LÉ, Amorim DA, Rozane DE, Parent SÉ, Natale W, Modesto VC. Nitrogen and potassium fertilization in a guava orchard evaluated for five cycles: effects on the plant and on production. $\mathrm{R} \mathrm{Bras} \mathrm{Ci}$ Solo. 2016 Ago;40:1-12, doi: 10.1590/18069657rbcs20140532

17. Mallmann N. Efeito da adubação na produtividade, qualidade e sanidade de batata cultivada no centro-oeste paranaense. [dissertação]. Curitiba: Universidade Federal do Paraná. 2001. 129 p.

18. Amtmann A, Troufflard S, Armengaud P. The effect of potassium nutrition on pest and disease resistance in plants. Physiol Plant. 2008 Mar;133(4):682-691, doi: 10.1111 / j.1399-3054.2008.01075.x

19. Romheld V. Role of potassium, calcium, magnesium and phosphorus on disease resistante. In: Simpósio sobre relações entre nutrição e incidência de doenças de plantas, Piracicaba, 2005. 263 p.

20. Reifschneider FSB. Produção de batata. Brasília - DF: Linha Gráfica e Editora. 1987. 239 p. 
21. Azevedo LAS. Manual de quantificação de doenças de plantas. São Paulo: Novartis Biociência-Setor Agro; 1997. $114 \mathrm{p}$.

22. Malavolta E, Vitti GC, Oliveira AS. Avaliação do estado nutricional das plantas: princípios e aplicações. Piracicaba: Potatos. 1997. 319 p.

23. Carvalho AMX, Mendes FQ. SPEED Stat: a minimalist and intuitive spreadsheet program for classical experimental statistics. In: Anais da $62^{\mathrm{a}}$ Reunião Anual da Região Brasileira da Sociedade Internacional de Biometria; 2017. $333 \mathrm{p}$

24. Allison MF, Fowler JH, Allen EJ. Responses of potato (Solanum tuberosum) to potassium fertilizers. J Agric Sci. 2001 Jun;136(4):407-426, doi: 10.1017/S0021859601008863.

25. Zaag DE. Van der. La patata y su cultivo en los Países Bajos. Haya. Holanda: Publicado por el Instituto Consultivo Holandés sobre la Patata. 1993. 76 p.

26. Cardoso AD, Alvarenga MAR, Melo TL, Viana AES. Produtividade e qualidade de tubérculos de batata sob diferentes e doses e parcelamentos de nitrogênio e potássio. Ciênc Agrotec. 2007 Nov;31(6):1729-1736, doi: 10.1590/S1413-70542007000600019.

27. Abuley LK, Nielsen BJ. Evaluation of models to control potato early blight (Alternaria solani) in Denmark. Crop Prot. 2017 Dez;102:118-128, doi: 10.1016/j.cropro.2017.08.012.

28. Blachinski D, Shtienberg D, Dinoor A, Kafkafi U, Sujkowski LS, Zitter TA, Fry WE. Influence of foliar application of nitrogen and potassium onalternaria diseases in potato, tomato and cotton. Phytoparasitica. 1996 Dez;24(4):281-292.

29. Zambolim L, Ventura JÁ. Resistência a doenças induzidas pela nutrição mineral das plantas. In: Revisão Anual de Patologia de Plantas. 1993. p. 318.

30. Silva AA. Adubação Mineral e orgânica em repolho III. Qualidade e ocorrência de Xanthomonas campestres pv. Campestris. Hortic Bras. 1986;4 (2):10-12.

31. Santos MC, Junqueira AMR, Freitas LM. Efeito do silício, nitrogênio e potássio na incidência da traça-dotomateiro em plantas para processamento industrial. Rev Bras Agropec Susten. 2013 Dez;3(2):19-24, doi: 10.21206/rbas.v3i2.213

32. Hannan A, Arif M, Ranjha AM, Abid A, Fan XH, Li YC. Using Soil Potassium Adsorption and Yield Response Models to Determine Potassium Fertilizer Rates for Potato Crop on a Calcareous Soil in Pakistan. Comum. Soil Science Plantar Anal. 2011 Mar;42(6):645-655, doi: 10.1080/00103624.2011.550378.

33.Zörb C, Senbayram M, Peiter E. Potassium in agriculture - status and perspectives. J Plant Physiol. 2014 Mai;171(9):656-669, doi: 10.1016/j.jplph.2013.08.008.

34. Murphy HJ, Cunningham CE, Hawkins A. Potato nutrition (fertilization) and culture. Am Potato J. 1963;8:7176.

35. Kang W, Fan M, Ma Z, Shi X, Zheng H. Luxury Absorption of Potassium by Potato Plants. Am J Potato Res. 2014 Out;91(5):573-578, doi: 10.1007/s12230-014-9386-8

36. Lalitha M, Dhakshinamoorthy M. Quantity-intensity characteristics of Potassium (K) in relation to potassium availability under different cropping system in alluvial soils. Afr J Agric Res. 2015 Mai;10(19):2097-2103, doi: 10.5897/AJAR2014.8947.

37. Amini S, Naeini SARM, Mashayekhi K. Effects of paper-mill sludge as a mulch versus topsoil incorporation on potassium uptake and the grain yield of rain-fed wheat in a high specific surface loess soil with illite dominance in clay fraction. Appl Environ Soil Sci. 2012;12:1-10, doi: 10.1155/2012/624824. 